\title{
Editorial: Fire safety engineering design of concrete structures
}

Long-yuan Li BEng, MSc, PhD, FIStructE

Professor of Structural Engineering, School of Engineering, University of Plymouth, UK

Reducing deaths in fires and the impact of fire damage on buildings requires a comprehensive approach to fire safety. The structural fire safety capacity of concrete is very complicated because concrete is a heterogeneous material with considerable variations. When concrete is subject to sufficient heat such as from a fire the free water that fills the concrete pores and water chemically bound to the cement will evaporate. If the evaporation rate is greater than the vapour migration rate, pore pressure will build up. This built-up pore pressure, combined with the reduction in strength caused by elevated temperatures and the increase in stresses due to thermal effect, can cause concrete spalling and damage to structures. In addition, developments in concrete mix design have led to new types of concrete - including high-strength, ultra-high-strength and self-compacting concrete - which, besides having an increased structural performance at ambient temperature, have also shown a different performance when exposed to fire. The importance of understanding the behaviour of concrete materials in fire is very certain. This special themed issue of Magazine of Concrete Research contributes to our understanding of what has been achieved and what remains to be done in order to provide the fire safety engineering design and improved fire performance of concrete structures.

This themed issue contains seven papers and presents results from both experimental and numerical studies on the fire behaviour of various concrete structures, ranging from the mechanical properties of concrete and steel reinforcement at elevated temperatures to the overall performance of concrete structures in fire.

In the paper presented by Wei et al. (2017) the authors investigated the effects of transient creep strain of concrete on post-tensioned concrete slabs with unbonded tendons by using three-dimensional nonlinear finite-element analysis models. In their study, three concrete constitutive models were employed, one without transient creep strain and the other two with either explicit or implicit consideration of transient creep strain. The results showed that, the model without transient creep strain is too conservative in fire scenarios by giving much larger deflection and higher tendon stress although the model is sufficiently accurate at ambient temperature. In contrast, the models with transient creep strain were found accurate in fire scenarios. However, if the transient creep strain was overestimated, the slab deflection and tendon stress would be reduced, indicating that the transient creep strain has a positive effect on structural fire resistance. Thus it was concluded that the transient creep strain should be considered in the analysis by either an implicit or an explicit approach for its positive contribution to the fire resistance of post-tensioned concrete slabs.

The paper contributed by Zhang et al. (2017) was on the mechanical properties of pre-stressing steel both in and after the fire. Empirical formulae were proposed based on experimentally obtained results for the degradation of Young's modulus, yield strength and ultimate strength of pre-stressing steel both at elevated temperatures and after cooling to ambient temperature. It was found that the Young's modulus was largely recoverable upon cooling to ambient temperature, but the yield and ultimate strengths suffered permanent degradation. It was recommended that for pre-stressed concrete structures reduction factors for the key mechanical properties after fire and cooling should be incorporated in the relevant design codes.

The paper presented by Arslan et al. (2017) provides an evaluation of fire performance of two large-scale industrial buildings in Turkey, destroyed by fires in 2011 and 2012. The structural frameworks used in these two buildings were prefabricated concrete and prefabricated concrete-steel (hybrid). The post-fire performance of the structures was evaluated according to the structural system properties of the buildings and tests on concrete core and steel reinforcement samples obtained from the structures. It was found that the concrete in the first building exposed to the longer fire duration suffered a substantial loss in mechanical properties, the concrete cover in reinforced concrete (RC) elements failed completely, and there was a significant loss in the yield strength of the steel reinforcement. The second building experienced a fire of shorter duration, although the concrete cover had failed similarly to the first one, there was no substantial loss in the mechanical properties of the reinforcement and concrete.

The paper presented by Gao et al. (2017) was on the fire resistance of RC beams when exposed to fire. The paper consists of 
four parts. The first part provides a review of design fire scenarios and existing time equivalence methods for fire resistance evaluation of structural members exposed to fire. The second part is concerned with finite-element modelling for predicting the fire performance of $\mathrm{RC}$ beams and its use in parametric study. In the third part a modified time equivalence method was proposed for predicting the fire resistance of $\mathrm{RC}$ beams exposed to fire. An example was provided in the fourth part to illustrate the application of the proposed method in practical design.

Choi et al. (2017) presented a review of recent research results for the prevention of the explosive fracture of concrete exposed to high temperatures, analysis of the fire resistance of concrete and recent fire mitigation construction methods. In addition, the paper also briefly described existing specifications for fire resistance design methods used in South Korea. It was shown from thermal gravimetric analysis, X-ray diffraction analysis and nuclear magnetic resonance test results that the fire resistance performance of RC structures by measuring rebar temperature underestimates the failure of the calciumsilicate-hydrate (C-S-H) structure in the concrete. It was recommended that in the near future performance-based design should be used for the fire resistance prediction.

The paper presented by Wu et al. (2017) was on the fire behaviours of concrete columns with prior seismic damage. In this study Wu et al. conducted the fire tests of 16 pre-damaged RC columns (two columns for each specimen and each specimen was first subjected to cyclic loadings at room temperature to produce simulated seismic damage) and two control columns without pre-damage. The influences of the intended drift ratio, axial load ratio, volumetric transverse reinforcement ratio and shear span ratio of the column on the fire behaviour of the tested columns were examined in detail. It was concluded that the axial load ratio of $\mathrm{RC}$ columns in high seismic intensity regions should be strictly limited to lower than $0 \cdot 5$.

In the paper presented by Wong and Liu (2017) a novel approach was proposed to the structural fire design of a concrete beam reinforced with hybrid steel-shape memory alloy (SMA) bars to achieve a desired fire resistance level.
The method is to embed both the steel and SMA bars in such a way that the strength of the beam is increased or maintained in a controlled manner as the temperature in the concrete beam increases, which provides an active method for structural fire protection as opposed to most traditional methods of passive protection for structural members. By being able to maintain the bending capacity of the beam in fire at a desirable level, excessive deformation of the beam can be avoided. The concept can be extended to the design of other structural elements such as columns, floor slabs and connections.

In summary, the papers in this special issue draw on the experience and special knowledge of academics and practitioners both in the public and private sectors in the UK, China, Turkey, South Korea and Australia. The efforts of these authors and the critical assessment of the papers by reviewers, whose time and expertise are reflected in the quality of this publication, are gratefully acknowledged.

\section{REFERENCES}

Arslan MH, Erdoğan O, Köken A, Erkan IH and Doğan G (2017) Evaluation of fire performance of prefabricated concrete buildings in Turkey. Magazine of Concrete Research 69(8): 389-401, http://dx.doi.org/10.1680/jmacr.15.00306.

Choi W-C, Kim S-W, Jang S-J and Yun H-D (2017) Research trends and design guidelines for fire resistance of structural concrete in South Korea. Magazine of Concrete Research 69(7): 347-364, http://dx. doi.org/10.1680/jmacr.15.00361.

Gao W-Y, Dai J-G and Teng J-G (2017) Fire resistance of RC beams under design fire exposure. Magazine of Concrete Research 69(8): 402-423, http://dx.doi.org/10.1680/jmacr.15.00329.

Wei Y, Au FTK, Li J and Tsang NCM (2017) Effects of transient creep strain on post-tensioned concrete slabs in fire. Magazine of Concrete Research 69(7): 337-346, http://dx.doi.org/10.1680/jmacr. 15.00266 .

Wong B and Liu J (2017) A hybrid steel-shape memory alloy reinforced concrete beam design for optimum fire resistance capacity. Magazine of Concrete Research 69(7): 327-336, http://dx.doi. org/10.1680/jmacr.15.00259.

Wu B, Xiong W and Liu F (2017) Fire behaviours of concrete columns with prior seismic damage. Magazine of Concrete Research 69(7): 365-378, http://dx.doi.org/10.1680/jmacr.15.00497.

Zhang L, Wei Y, Au FTK and Li J (2017) Mechanical properties of prestressing steel in and after fire. Magazine of Concrete Research 69(8): 379-388, http://dx.doi.org/10.1680/jmacr.15.00267. 